\title{
An ecological perspective on minority and majority language and literacy communities in the Americas*
}

\author{
Una perspectiva ecológica de la primera y segunda \\ lengua en las comunidades letradas de las Américas
}

\author{
Iliana Reyes \\ Assistant Professor \\ Department of Language, Reading and Culture \\ University of Arizona, USA \\ E-mail: ireyes@email.arizona.edu
}

\begin{abstract}
In this paper I discuss current sociolinguistic situations in linguistically diverse communities in the Americas, thereby contributing toward the development of a theoretical model that focuses on the ecology of emergent bilingualism and biliteracy for both language-minority and language-majority children. I analyze different examples in which children's participation during family literacy events mediate the learning of the second language and their construction of meaning from print they encounter in their bilingual surroundings. The review points to the potential to develop bilingualism and biliteracy that might exist within each child's immediate environment and are enhanced when community members (e.g., parents, peers, schoolteachers, neighbors) provide direct scaffolding during child-adult interactions. The studies are discussed within an eco-sociocultural framework making pedagogical connections and recommendation to the optimal development of bilingualism and biliteracy.
\end{abstract}

Key words: children bilingualism and biliteracy, language learning, native and second languages, language policies

\section{Resumen}

En este artículo se analizan situaciones sociolingüísticas actuales en comunidades lingüísticamente diversas en las Américas, para contribuir al desarrollo de un modeo teórico enfocado en la ecología del bilinguismo y bialfabetismo emergentes tanto para niños usuarios de su lengua materna como para aprendices de una segunda lengua. Se analizan diferentes ejemplos en los cuales la participación de los niños en experiencias de lectura y escritura en familia media el aprendizaje de la segunda lengua y la construcción de significado a partir de los textos que ellos encuentran en su ambiente bilingüe. La revisión resalta el potencial para desarollar el bilinguismo y el bialfabetismo que pueden existir en el ambiente letrado de cada uno de los niños y los amplía cuando los miembros de su comunidad (padres, maestros, vecinos) construyen una estructura de apoyo en sus interacciones con los niños. Se discuten dentro de un marco eco-sociocultural que ofrece conexiones pedagógicas y recomendaciones para el óptimo desarrollo del bilingüismo y bialfabetismo.

Palabras claves: bilingüismo y bialfabetismo en niños, aprendizaje de lengua, lengua materna y segundas lenguas, políticas lingüísticas

* $\quad$ Received 31-01-09 / Approved 15-04-09 


\section{Introduction}

To date most research in the bilingual education field has focused on the development of individual children's bilingual skills. Even though sociocultural and political factors impact the sociolinguistic situation for language-minority families and for children who grow up learning more than one language, these factors have been largely ignored. In this paper I discuss current sociolinguistic situations in linguistically diverse communities in the Americas, ${ }^{1}$ thereby contributing toward the development of a theoretical model that focuses on the ecology of emergent bilingualism and biliteracy for both language-minority and language-majority children. Drawing examples from my own fieldwork and from the scholarly literature, I explore how various bilingual, and in some cases monolingual, interactions in which children participate mediate their learning of a second language and their construction of meaning from the print they encounter in their bilingual surroundings. I then discuss the pedagogical implications of these examples for the implementation of bilingual education and for supporting the development of biliteracy and second-language acquisition in naturalistic home and classroom settings.

Bilingualism develops when speakers participate in day-to-day activities that require them to use two languages. For example, it may be advantageous to speak to family members in their native language but use a different language in the broader community (Wong Fillmore, 1991). Researchers have also documented cognitive advantages of bilingualism, which include greater mental flexibility when solving problems that involve distractions and earlier acquisition of metalinguistic awareness in childhood (Bialystok, 2001; Genesee, 2001). Beyond the cognitive and linguistic competence aspects of bilingualism,

1 Here I use Americas to include North, Central, and South America. there are sociocultural and political aspects of bilingualism and biliteracy to be considered. Specifically, as bilingual speakers develop their native language along with the dominant language, they also become bicultural and experience a diverse range of sociocultural experiences that in turn impact their level of bilingualism.

\section{Language and Sociopolitical Factors}

Bilingualism and biliteracy often occur in a sociopolitical context of asymmetric power relationships, in which one language has higher status than the other (Hornberger $\mathcal{E}$ SkiltonSylvester, 2000; Skilton-Sylvester, 2003). Because of this, it is imperative to frame theories of bilingualism and biliteracy development within a critical view that accounts for the language ideologies and sociopolitical factors that either enable or hinder the development of biliteracy and affect the ways in which children internalize and position themselves in different social contexts. Unfortunately, current educational policies in the United States and in Latin American countries often impose politically motivated language policies and curricula that do not meet children's needs and deliberately marginalize their native languages (Combs, Evans, Fletcher, Parra, \& Jiménez, 2005; de Mejía, 2006; López, 2008).

For example, some U.S. states have passed English-only laws that prohibit the use of any language other than English for instructional purposes in the classroom (e.g., Proposition 203 in Arizona and Proposition 227 in California). In Arizona, this law eliminated most bilingual programs, replacing them with structured English immersion (SEI) programs that allow immigrant students only one year to become proficient in English before being mainstreamed into regular classes taught in English. In addition, the label English Language Learners (ELLs) that replaced the term Limited Proficiency English (LEP) at the federal level continues to target the learning 
of English only from a subtractive perspective where no attention or concern is accorded to the maintenance or significance of the students' heritage language. Combs et al. (2005) have documented that not only do immigrant children learn English more slowly in SEI programs because they lack the support of their home language, but more critically, this policy is "making schooling a deeply traumatic event for some ELLs, and for SEI teachers a stressful and frustrating experience" (p. 721).

Even students who attend schools in states where there is no English-only policy typically encounter discourses and practices that privilege the dominant language over their native language. For example, Skilton-Sylvester (2003) reported that a teacher's personal attitudes and ideologies about the relative value of the English versus Khmer languages created micro-level language policies that shaped the opportunities Vietnamese students had to develop literacy in Khmer. Even though these students were living in a multicultural community in Philadelphia where they used Khmer during their daily interactions, they had limited opportunities to develop their proficiency in that language in the classroom. Thus, federal and state policies and discourses that identify English as the language of power strongly influence teachers' ideologies and consequently their implementation of literacy activities in the school context in ways that negatively affect young minority children's learning experiences.

Similarly, in Mexico, the sociopolitical dimensions of the debate over language policies for minority indigenous communities (often enacted by policymakers who are members of the dominant mestizo community) revolve around two key questions (Hamel, 2008): Should members of indigenous communities be forced to assimilate and give up their ethnic identity and language in order to become accepted citizens of the nation? And, Could indigenous peoples integrate into and acquire full membership in the dominant mestizo society while simultaneously preserving and fostering their own identity and diversity?

These questions are not exclusive to the Mexican context but also apply in the rest of Latin America, where even though indigenous communities have launched some language maintenance and revitalization efforts, the Spanish language dominates the literacy practices at school and permeates the homes of language-minority families (Hammel, 1996; Scanlon E Lezama Morfín, 1982). Yet a diglossic language situation perpetuates ongoing conflict between Spanish and indigenous languages. Competing language practices between the home and school contexts affect young children's learning experiences and the ways in which they "unofficially" develop literacy in the two languages. The subtractive language environments they experience at school, where "English only" is emphasized to children and they are restricted and penalized for speaking the native language in the classroom, not only prevent teachers from using a child's native language as an educational resource in the classroom, but also negate the contributions of children's families and extended social networks in promoting early language and literacy development (Zentella, 2005).

\section{An Ecological Perspective on Early Childhood Bilingualism}

An important theoretical perspective guiding my understanding of biliteracy and language practices is the ecology of language, adapted from the work of Haugen (1953) and later integrated into Hornberger's continuum of biliteracy model (Hornberger, 1989; Hornberger \& SkiltonSylvester, 2000). These researchers proposed the ecology of language concept to describe the ideologies underlying language practices 
and policies in multilingual communities. This perspective highlights how bilingualism and biliteracy interact with the sociopolitical, economic, and cultural language environments in which individuals interact. Through a review of recent studies in different parts of the Americas I adapt the metaphor of the ecology of language to the study of biliteracy and second language acquisition in order to shed light on the ecological environments and complex interrelationships among the different factors that influence young bilinguals' biliteracy development (e.g., languages used, their speakers, their interpretations of text; Reyes, 2008a, Reyes, 2008b; Reyes \& Azuara, 2008).

Specific to the study of the ecology of language in multilingual settings, Hornberger (1989) and Hornberger and Skilton-Sylvester (2000) propose to situate language planning research within a theoretical framework of biliteracy. This model proposes an array of continua representing a series of complex, interrelated dimensions (social level) that account for the individual speaker and the context, media, and content of language use. At the individual level, biliteracy development is represented as occurring on a dynamic continuum that is infinite rather than having polar opposite endpoints. Important to this model is that literacy is viewed as social practice, thus highlighting the social context in which biliteracy is nested. For the study of bilingualism, biliteracy, and second language acquisition I pay particular attention to the dimension of sociocultural context and how it comes into play when children participate in literacy events at home and school.

\section{A Longitudinal Perspective on Bilingualism and Biliteracy Development}

In this section I review findings from two studies that took an ecological approach to children's literacy development at home and in the community. The first is my longitudinal research project on bilingualism and second language acquisition in the U.S. Southwest. I then connect the findings from this study to Azuara's (2007) research in a Maya community in the Yucatan Peninsula. Among several research questions related to emergent biliteracy in young preschool children, two central questions have guided my research:

- How do young emergent bilinguals develop biliteracy in their everyday sociocultural contexts (home, school, communities)?

- What are the various sociocultural factors that influence the ways in which parents and teachers support children's potential to become bilingual and biliterate in Spanish and English?

As part of this longitudinal study, I videotaped the children and their families at home every other week, and videotaped children in the classroom weekly to document the literacy practices they participated in. I also collected examples of their emergent writing from school and home to follow their literacy development. My focus was on language and literacy practices observed during natural interactions at home and in the community.

The children and their families were mostly first-generation immigrants living in a predominantly Latino neighborhood in southern Arizona. Driving through this community one sees the influence and presence of the Mexican culture in stores, churches, and other public places, and many announcements, billboards, and signs are printed in either Spanish or both languages. The children attended a local preschool program originally designed as a bilingual program for working-class children.

From my observations from the time children began preschool through entry into first grade, I learned that all of the families promoted Spanish 
maintenance through home and community activities. More specifically, some families actively promoted literacy development (reading and writing) in the native language at home. For example, some families went to the public library and consciously deliberately checked out Spanish or bilingual books to make sure their children had opportunities to read and listen to stories in Spanish. In some cases, mothers, or grandmothers who lived with the families, expressed a strong interest in maintaining the native language because they saw a high value in developing bilingual abilities that could become a very marketable job skill for their children in the future.

A summary of the findings across families indicate that

- both school and home contexts were central to biliteracy learning for these children; however, experiences at home were critical in facilitating the development and maintenance of the native language.

- children use all their linguistic resources in both languages to make sense of print and literacy in their environments, and they construct different hypotheses about written language in both Spanish and English.

- there is a bidirectional learning of language across generations where both children and adults benefit from each other's knowledge of English and Spanish.

Following a similar ecological approach to the study of language and literacy development, Azuara (2007) studied Maya-speaking children and their families in a rural community of Yucatan. Although Maya is the first language for most adults and children, many children are becoming passive bilinguals who can understand Maya but rarely or never speak it. Moreover, when they start school the children face the challenge of learning Spanish as their second language with little support from their native language and frequently encounter negative attitudes toward the use of Maya in the school context. One important finding from Azuara's study is that these children seldom engaged in literacy activities with adults outside of school. Interactions between adults and children focused on daily routines (e.g., feeding; bathing; playing lotería, a game similar to bingo) and most importantly on the exchange of the family members' funds of knowledge (González, Moll, \& Amanti, 2005). It is in the analysis of these daily practices that applying an ecological perspective to literacy development is most important, because although the children may not be directly exposed to conventional literacy in Maya, these interactions still influence how they learn both Maya and Spanish.

Both Reyes' (2008b) and Azuara's (2007) findings reveal that children's acquisition of the dominant and native languages is determined by the functions for which language and literacy are used in specific ecological contexts. That is, if appropriate contexts and speakers exist to provide these children with the tools and mediators they need to acquire the minority language, they have the potential to develop bilingualism and perhaps also biliteracy. Even though the children were living in bilingual (Spanish-English and MayaSpanish, respectively) and bicultural communities where they used the minority language during their daily life experiences, they had limited opportunities to develop literacy in that language as part of their formal educational and schooling experiences.

\section{Bilingual Contexts in South America}

Recent research in South America has highlighted that minority groups there also face complex sociolinguistic situations where immersion in the dominant culture creates pressures that decrease their use and knowledge 
of their native language. For example, de Mejía (in press) reviews the sociolinguistic situation and potential for trilingualism that exists within the Archipelago of San Andrés, Providencia, and the Santa Catalina Islands, which are Colombian territories in the Caribbean Sea. She focuses on how various factors influence the use of three languages-Spanish, standard Caribbean English, and English Creole (commonly known among locals as "Islander English")-across speakers. Although these islands are considered a multilingual community, fluency in standard English and Creole are declining due to the rapidly increasing use of Spanish in public contexts that is driven by Colombian immigrants from the mainland.

Interestingly, although Spanish is the medium for instruction and learning in most schools, the majority of teachers on the islands speak Creole as their first language and have mastered only oral communication in Spanish, which makes it difficult for them to instruct their students in academic Spanish. This situation has sparked the recent Pilot Trilingual Project, which supports and honors the use of Creole for instruction in the school context (Bowie $\mathcal{E}$ Dittmann, 2007). Children at the project school have been observed constantly code-switching as they interact with monolingual Spanish-speaking students and with other Creole native speakers (Moya Chaves, 2004 as cited in de Mejía, in press). As the school project continues, teachers' and students' attitudes are evolving with regard to which language they prefer to use, how Creole should be used at school, and how to maintain local Creole culture and traditions.

Another example comes from a Bolivian community where Luykx (2003) describes discourse practices by Aymara children and their families. These young children learn Aymara, the local indigenous language, but also develop a command of Spanish because they are aware of the social stigma attached to their native language. Luykx notes a decrease in Aymara language competence among families that migrate to urban settings where the children learn Spanish. Luykx reports that generally only the older siblings remain fairly fluent in Aymara. Younger siblings tend to develop limited competence in Aymara or may abandon the language altogether, mostly due to pressure from school, peer culture, and the popular media to embrace Spanish and reject their indigenous family language. Like other bilingual children and families throughout the Americas, they also find themselves torn between competing language practices at home and in the larger community, including the school.

On the other end of the language continuum, de Mejía (2006) describes the tendency in Latin American countries to focus on developing bilingualism in so-called prestigious languages, such as English-Spanish or French-Spanish. This "elite" bilingualism often occurs at the expense of bilingualism in local indigenous languages. For example, she is critical of Colombia's recent "Bogotá Bilingüe" language policy, which seeks to make the country's capital economically competitive with English-speaking countries by privileging Spanish-English bilingualism. She and other Colombian academics have voiced concern about this exclusive focus on English, a language that already holds tremendous power and prestige. She argues that every Latin American country needs to develop equitable language policies that encompass all the languages and cultures represented in that country. De Mejía (2006, p. 155) counters that a "multicultural and plurilingual nation needs a language policy which takes into account not only exolingual, but also endolingual concerns" of the nation's linguistic communities.

These studies point to the combination of factors that mediates how language-minority children learn two or more languages and whether 
they acquire literacy in their native language. The examples highlight that children's and adults' attitudes about the use of the minority and majority languages in different contexts impact children's acquisition of their second language and maintenance of their first. Because of this interplay I support the efforts to shift the way we think about and perceive the use of minority languages, in particular indigenous languages, in education in the direction of an integrated ecological model of language and learning. This ecological model is similar to the whole-language approach, in that "meaning and content are regarded as more important than form, and the classic distinction between L1 and L2 may not apply as rigidly as it used to" (López, 2008, p. 146) because of the speakers' range of language competencies.

\section{Bilingualism for All: Educational Programs and Opportunities for Minority and Majority Children}

The term bilingual education has been used to refer to a range of educational programs; in the United States English is the majority language in this type of program, and because of the number of immigrants from Latin America, Spanish is the most commonly supported second language. There are however bilingual programs that support and provide instruction in Cantonese, Navajo, and Korean, among other languages. The debate over how bilingual education should be structured hinges on people's different perspectives on the teaching and learning of languages. For example, subtractive bilingual programs devalue the native language, viewing it only as a way to help students reach competence in English. Their goal is to transfer students to mainstream English instruction and eliminate use of the native language as soon as they have achieved basic competence in English.
In contrast, additive bilingual programs have as their goal to promote both bilingualism and biliteracy as part of the general curriculum. This type of program acknowledges and draws on the families' linguistic and cultural funds of knowledge to make children's educational experiences more meaningful (Baker, 2006).

A subtype of additive bilingual programs is intercultural education, which takes an additive approach to the development of a second language. Intercultural education has predominantly been used in the context of educating indigenous but not necessarily Spanish-speaking children in Latin America. Recently, de Mejía (2008) has argued that the traditional dichotomy between the bilingual education programs offered to speakers of the majority language and those available to minority-language speakers in Colombia should be reconsidered within a wider, integrated vision of bilingual education. She states that there "are significant areas of convergence between these different traditions in relation to issues such as the maintenance of cultural identity, the status and development of the first language, and the importance of contextual factors in the design and modification of bilingual education programmes" (p. 329). She then outlines how enrichment bilingual education programs for majority students should include this component of integrating aspects and understanding of both languages and cultures in order to increase students' fluency in and sensitivity for the nations' local languages. In sum, all children, minority and majority, could benefit from bilingualism if we made those opportunities available to them and supported it as another element of our communities.

\section{Implications}

The ecological approach considers bilingualism and biliteracy in the context of political, social, cultural, and ideological 
influences. This review points to ways community members (e.g., parents, peers, schoolteachers, neighbors) could enhance the potential for bilingualism, biliteracy, or even trilingualism that might exist within each child's immediate environment by providing direct support for use of multiple languages as part of classroom and community literacy practices.

Adopting an ecological model of bilingual and biliteracy development in minority communities has important research, policy, and practical implications. From a research perspective, there is a strong need to conduct longitudinal studies of language ecology and socialization in bilingual or multilingual classrooms, as well to learn about children's use of language at home and in community activities (Bayley \& Schecter, 2003, Quintero, 2006). In terms of policy, there is a great need to consider and include current research in the design and development of language policies and programs. Finally, teachers can assist second language learners by:

- understanding the connection between culture and maintenance of a second language.

- promoting the acquisition of communicative competence in both languages.

- recognizing how attitudes toward the majority and minority languages affect acquisition of fluency and literacy in the minority language.

- taking time to find out how students use both languages in contexts outside of school (e.g., home, family) where teachers do not typically observe them.

A language ecology approach to the study of bilingualism and second language acquisition studies language not as "an isolated, selfcontained system," but in the context of all "its natural surroundings in relation to the personal, situational, cultural, and societal factors" impacting the speakers' language experiences
(Kramsch E Steffensen, 2008). Finally, this approach has a rich potential for transforming language and literacy practices in the classroom because it allows for investigation of how a student's native language socialization at home influences his or her acquisition of bilingualism and biliteracy in the classroom context.

\section{References}

Azuara, P. (2007, November). Literacy development in a changing cultural context: A study of literacy practices in a Mayan community in Yucatan, Mexico. Paper presented at the 106th meeting of the American Anthropological Association, Washington, DC.

Baker, C. (2006). Foundations of bilingual education and bilingualism. Clevedon, UK: Multilingual Matters.

Bayley, R., \& Schecter, S. R. (2003). Language socialization in bilingual and multilingual societies. Cleveland, Ohio: Multilingual Matters.

Bialystok, E. (2001). Metalinguistic aspects of bilingual processing. Annual Review of Applied Linguistics, 29, 169-181.

Bowie, P., \& Dittmann, M. (2007). El proyecto piloto trilingüe de la Universidad Cristian de San Andrés en las escuelas Emmanuel Bautista y Bautista Central en la Isla de San Andrés. In A. M. Truscott de Mejía and S. Colmenares (eds.), Bialfabetismo. Lectura y escritura en dos lenguas en Colombia. Cali: Universidad del Valle.

Combs, M. C., Evans, C., Fletcher, T., Parra, E., \& Jiménez, A. (2005). Bilingualism for the children: Implementing a dual-language program in an English-only state. Educational Policy, 19(5), 701-728.

de Mejía, A. M. (2006). Bilingual education in Colombia: Towards a recognition of languages, cultures and identities. Colombian Applied Linguistics Journal, 8,152-168.

de Mejía, A. M. (2008). Enrichment bilingual education in South America. In J. Cummins \& N. H. Hornberger (Eds.), Encyclopedia of Language and Education (Vol. 5, pp. 323-331). New York: Springer.

de Mejía, A. M. (In press). Multilingualism and pedagogical practices in the archipelago of San Andrés, Providencia and Santa Catalina. In C. Hélot \& M. O Laoire, (Eds.), Teaching in the multilingual classroom: Policies for pedagogy. Clevedon, UK: Multilingual Matters. 
Genesee, F. (2001). Portrait of the bilingual child. In V. Cook (Ed.), Portraits of the second language user (pp. 170-196). Clevedon, UK: Multilingual Matters.

González, N., Moll, L. C., \& Amanti, K. (2005). Funds of knowledge: Theorizing practices in households, communities, and classrooms. Mahwah, $\mathrm{NJ}$ : Lawrence Erlbaum Associates.

Hamel, R. E. (2008). Bilingual education for indigenous communities in Mexico. In J. Cummins \& N. H. Hornberger (Eds.), Encyclopedia of Language and Education (Vol. 5, pp. 311-322). New York: Springer.

Hammel, R.E. (1996). The inroads of literacy in the Hñähñú communities of Central Mexico. Internatioanl Jouranl of the Sociology of Language, 119, 13-41.

Haugen, E. (1953). The Norwegian language in America: A study in bilingual behavior. (Vols. 1-2). Philadelphia: University of Pennsylvania Press. Reprinted: Bloomington: Indiana University Press.

Hornberger, N. H. (1989). Continua of biliteracy. Review of Educational Research, 59, 271-296.

Hornberger, N. H., \& Skilton-Sylvester, E. (2000). Revisiting the continua of biliteracy: International and critical perspectives. Language and Education: An International Journal, 14(2), 96-122.

Kramsch, C., \& Steffensen, S. V. (2008). Ecological perspectives on second language acquisition and socialization. In P. A. Duff \& N. H. Hornberger (Eds.), Encyclopedia of Language and Education (Vol. 8, pp. 17-28). New York: Springer.

López, L. E. (2008). Indigenous contributions to an ecology of language learning in Latin America. In A. Creese, P. Martin \& N. H. Hornberger (Eds.), Encyclopedia of Language and Education (Vol. 9, pp. 141-155). New York: Springer.

Luykx, A. (2003). Weaving language together: Family language policy and gender socialization in bilingual
Aymara households. In R. Bayley \& S. R. Schecter (Eds.), Language socialization in bilingual and multilingual societies (pp. 25-43). Cleveland, Ohio: Multilingual Matters.

Quintero, L. M. (2006). School Literacy Practices Closer to Home: The New Challenge of Literacy Learning. Colombian Applied Linguistics Journal, 8, 216-227.

Reyes, I. (2008a). Bilingualism: A holistic view. In J. González (Ed.), Encyclopedia of Bilingual Education in the US. Thousand Oaks, CA: Sage Publications.

Reyes, I. (2008b). Bilingualism in the Americas: Toward an ecological model for theory, research, and practice. Keynote presentation to the Thirteenth Round Table in Applied Linguistics, Universidad Distrital Francisco José de Caldas, Bogotá, May 29-30, 2008.

Reyes, I., \& Azuara, P. (2008). Emergent biliteracy in young Mexican immigrant children. Reading $R e-$ search Quarterly, 43, 4.

Scanlon, A. P., \& Lezama Morfín, J. (Eds.). (1982). México pluricultural: De la castellanización a la educación indígena bilingüe bicultural. Mexico City: SEP-Porrúa.

Skilton-Sylvester, E. (2003). Legal discourse and decisions, teacher policymaking and the multilingual classroom: Constraining and supporting Khmer/ English biliteracy in the United States. International Journal of Bilingual Education and Bilingualism, 6 (3 \& 4), 168-184.

Wong Fillmore, L. (1991). When learning a second language means losing the first. Early Childhood Research Quarterly, 6, 323-346.

Zentella, A. (2005). Building on strength: Language and literacy in Latino families and communities. New York: Teachers College Press; Covina, CA: Association for Bilingual Education. 